
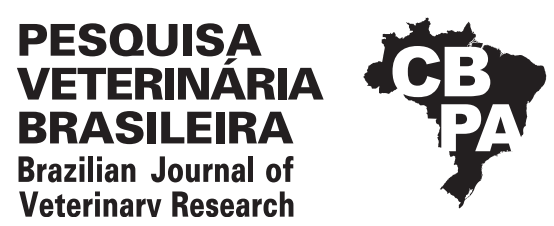

Pesq. Vet. Bras. 40(2):82-87, February 2020 DOI: 10.1590/1678-5150-PVB-6259

Original Article

ISSN 0100-736X (Print)

Livestock Diseases

ISSN 1678-5150 (Online)

\title{
Microbiological and molecular detection of Mycoplasma bovis in milk samples from bovine clinical mastitis ${ }^{1}$
}

\author{
Anelise Salina ${ }^{2}$, Jorge Timenetsky ${ }^{3}$, Maysa S. Barbosa ${ }^{3}$, Cristiane M. Azevedo ${ }^{4}$ \\ and Helio Langoni ${ }^{2 *}$ (D)
}

\begin{abstract}
Salina A., Timenetsky J., Barbosa M.S., Azevedo C.M. \& Langoni H. 2020. Microbiological and molecular detection of Mycoplasma bovis in milk samples from bovine clinical mastitis. Pesquisa Veterinária Brasileira 40(2):82-87. Departamento de Higiene Veterinária e Saúde Pública, Universidade Estadual Paulista, Rua Doutor Walter Maurício Correa s/n, Distrito de Rubião Júnior, Botucatu, SP 18618-681, Brazil. E-mail: hlangoni@fmvz.unesp.br

The genus Mycoplasma includes more than 200 bacterial species that cause disease in animals. It is responsible for causing mastitis in bovines and may be related to other manifestations, such as arthritis and pneumonia in calves and heifers. The present study aimed to detect Mycoplasma bovis isolated from milk samples of bovine clinical mastitis, and to compare the isolation rates in two culture media: Hayflick and SP4. An initial screening was performed in order to detect the presence of the class Mollicutes in 1166 milk samples from clinical mastitis by the conventional Polymerase Chain Reaction (PCR) technique. According to the 1166 milk samples evaluated, 8.6\% (100/1166) were positive to class Mollicutes. Regarding molecular analyses, 1.1\% (13/1166) of conventional PCR for positive M. bovis was obtained and $0.9 \%(11 / 1166)$ in real-time PCR. The results of the microbiological culture of the 100 samples previously screened demonstrated that $6 \%(6 / 100)$ of colony growth have been developed when using the Hayflick medium, and 11\% (11/100) when using the SP4 medium (including the positive on Hayflick medium). Concerning the 11 isolates obtained in the microbiological culture, conventional PCR confirmed M. bovis in nine of them, and two cultures were negative. In the phylogenetic analysis of the isolates, all of them were grouped in M. bovis and M. agalactiae clusters. The results confirmed the importance of the presence of $M$. bovis in the etiology of bovine clinical mastitis and reinforced the need for further studies to elucidate other Mycoplasma species that may be involved in bovine clinical mastitis in Brazil.
\end{abstract}

INDEX TERMS: Microbiology, molecular detection, Mycoplasma bovis, milk, bovine mastitis, mycoplasmosis, PCR, Mollicutes, cattle.

RESUMO.- [Detecção microbiológica e molecular de Mycoplasma bovis em amostras de leite oriundas de mastite clínica bovina.] 0 gênero Mycoplasma inclui mais de 200 espécies que causam doenças nos animais. É responsável

\footnotetext{
${ }^{1}$ Received on May 15, 2019.

Accepted for publication on June 9, 2019.

Doctoral research with financial support from CAPES.

${ }^{2}$ Departamento de Higiene e Veterinária e Saúde Pública, Universidade Estadual Paulista (Unesp), Rua Doutor Walter Maurício Correa s/n, Distrito de Rubião Júnior, Botucatu, SP 18618-681, Brazil. *Corresponding author: helio.langoni@unesp.br

${ }^{3}$ Instituto de Ciências Biomédicas, Departamento de Microbiologia, Universidade de São Paulo (USP), Av. Prof. Lineu Prestes 1374, Butantã, São Paulo, SP 05508-900, Brazil.

${ }^{4}$ Veterinarian, Qualy \& Calf Consultoria Veterinária, Rua Vereador Alcides da Silva Reis 41, Wenceslau Braz, PR 84950-000, Brazil.
}

por quadros de mastite em bovinos, podendo também estar relacionado à outras manifestações como artrite e pneumonia em bezerros e novilhas. 0 presente estudo objetivou a deteç̧ão de Mycoplasma bovis isolados a partir de amostras de leite de mastite clínica bovina, bem como, a comparação da taxa de isolamento em dois meios de cultura: Hayflick e SP4. Para efeito de triagem amostral, foram avaliadas quanto à presença da classe Mollicutes 1166 amostras de leite de casos de mastite clínica pela técnica de PCR convencional. Das 1166 amostras de leite avaliadas, 8,6\% (100/1166) foram positivas à classe. Nas análises moleculares, obteve-se 1,1\% (13/1166) de positividade para Mycoplasma bovis na PCR convencional e 0,9\% (11/1166) na PCR em tempo real. Os resultados do cultivo microbiológico das 100 amostras triadas previamente demonstraram $6 \%(6 / 100)$ de crescimento 
de colônias ao se utilizar o meio Hayflick e 11\% (11/100) ao se utilizar o meio SP4 (incluindo as positivas ao primeiro). A partir dos 11 isolados obtidos no cultivo microbiológico, a PCR convencional confirmou Mycoplasma bovis em nove deles, e dois foram negativos para o agente. Na análise filogenética dos isolados, todos agruparam no cluster Mycoplasma bovis e Mycoplasma agalactiae. Frente aos resultados, ressalta-se a importância da presença de Mycoplasma bovis na etiologia da mastite clínica bovina e reforça a necessidade de estudos mais aprofundados para a elucidação de outras espécies de micoplasmas que possam estar envolvidas na mastite bovina.

TERMOS DE INDEXAÇÃO: Detecção molecular, microbiologia, Mycoplasma bovis, leite, mastite bovina, micoplasmose, PCR, Mollicutes, bovinos.

\section{INTRODUCTION}

Mycoplasma bovis is an important agent responsible for occasional respiratory problems, clinical mastitis, and sharp drop in milk production, especially in large herds (Aebi et al. 2012). On the other hand, regarding small herds with few numbers of animals, the manifestations resulting from the presence of $M$. bovis mainly occur in the form of arthritis and pneumonia in calves and heifers (Pfützner \& Sachse 1996).

More than 25 species belonging to the class Mollicutes cause mastitis and other clinical manifestations in dairy cattle (cows and heifers), such as: M. californicum; M. alkalescens; M. arginini; $M$. bovigenitalium; $M$. canadense; $M$. dispar; M. bovirhinis (Higuchi et al. 2013) and M. bovis (Aebi et al. 2012, Nicholas et al. 2016, Al-Farha et al. 2017). In Brazil, the first report of the disease in dairy cattle was from Mettifogo et al. (1996). So far, in Brazil, few studies have been conducted to elucidate the occurrence of Mycoplasma infection in the mammary glands in dairy herds. Junqueira et al. (2017) reported the occurrence of $M$. bovis (3\%) in samples of bovine clinical mastitis. Manzi et al. (2018), in a study regarding the occurrence of $M$. bovis in milk expansion tanks, obtained $1.4 \%$ for the same species.

The prevalence of $M$. bovis in the herds differs between studies. Al-Farha et al. (2017) obtained $76.7 \%$ of positive milk samples for Mycoplasma spp., and 6.2\% of them, M. bovis was detected. In a study conducted in herds in Japan, the prevalence of $M$. bovis was higher than in other species obtained in that study, representing $59.7 \%$ of the isolates (Higuchi et al. 2013). In southeastern France, the prevalence of clinical mastitis by this agent is less than 1\% (Arcangioli et al. 2011).

The identification of mycoplasmas in milk occurs through microbiological culture, considered the gold standard for detection of infections by this agent. Generally speaking, the technique is simple, but specific enrichment culture media are required for the different species involved in the etiology of mastitis (Brown et al. 2010), sometimes making the diagnosis laborious.

Molecular techniques are widely used to identify mycoplasma species involved in mastitis (Baird et al. 1999, Aebi et al. 2012, Higuchi et al. 2013). Among them, Polymerase Chain Reaction (PCR) is the most used then PCR allows rapid and sensitive result when compared to microbiological culture, furthermore, also has the possibility of identifying different species, depending on the use of different species primers.
Considering the importance of mastitis, its negative impact on the milk supply chain and the occurrence of $M$. bovis in dairy cattle reported in the national and international literature, the present study aimed to detect this pathogen by two techniques molecular: conventional and real-time PCR, as well as comparing the detection rate of the agent in two culture media, Hayflick and SP4.

\section{MATERIALS AND METHODS}

Samples. A total of 1166 milk samples of bovine clinical mastitis originated from nine dairy farms in the region were evaluated in the area of dairy basin ABCW (Arapoti, Batavo, Castro, Witmarsum), - in the state of Paraná (PR) and property located in Sao Pedro, in the state of São Paulo (SP), identified from 'A' to 'J'. All properties have highly technified bovine production system of bovine milk, being the only type of production. The evaluated milk samples were sent to the Núcleo de Pesquisa em Mastites - Universidade Estadual Paulista (Nupemas-Unesp, Botucatu) for the diagnosis of Mycoplasma spp. in the herds, therefore being considered as convenience samples.

DNA extraction. After receiving milk samples, $1 \mathrm{~mL}$ aliquots were kept in microtubes for bacterial DNA extraction. For sample screening, DNA extraction was performed following the thermolysis method described by Fan et al. (1995). An additional DNA purification step consists of adding $10 \%$ of the recovered volume of $3 \mathrm{M}$ sodium acetate solution (molar concentration $=3$ ). Then $2.5 \mathrm{x}$ of the recovered volume of $100 \%$ ice-cold $\left(4^{\circ} \mathrm{C}\right)$ ethanol was added, and the material was kept at $-20^{\circ} \mathrm{C}$ overnight (Kazemiha et al. 2009).

Conventional PCR for Mollicutes and Mycoplasma bovis. Incubation was performed in a Thermal Cycler Mastercycler Gradient (EppendorfThe reaction was prepared as follows: $12.5 \mu \mathrm{L} \mathrm{GoTaq}{ }^{\circledR}$ Green Master Mix (Promega), $1 \mu \mathrm{L}$ of each primer, $7.5 \mu \mathrm{L}$ ultra-pure water $\left(\mathrm{Gibco}^{\circledR}\right)$ and $3 \mu \mathrm{L}$ of extracted DNA to a final volume of $25 \mu \mathrm{L}$. Initially, class Mollicutes of DNA amplification was performed, and once positive, $M$. bovis DNA amplification was performed using the specific primers listed in Table 1. For all reactions, a reference strain $M$. bovis Donetta (ATCC 25523) was used as a positive control. Visualization of the amplified material was assessed by an electrophoretic run on $1.5 \%$ agarose gel plus $0.06 \mu \mathrm{L} / \mathrm{mL}$ Nancy (Sigma-Aldrich ${ }^{\circledR}$ ). The gel was visualized in UV light transilluminator and the image captured by an eletronic documentat system.

Real-time PCR for detection of Mycoplasma bovis. Taqman ${ }^{\circledR}$ real-time PCR was performed on equipment Applied Biosystems Step One ${ }^{\mathrm{TM}}$ (Applied Biosystems, Life Technologies Corporation). The real-time PCR reaction was prepared as follows: $12.5 \mu \mathrm{L} \mathrm{TaqMan}{ }^{\circledR}$ Universal PCR Master Mix (Applied Biosystems), 10 $\mu \mathrm{M}$ of each primer, $10 \mu \mathrm{M}$ TaqMan ${ }^{\circledR}$ probe, 20 ng or $1 \mu \mathrm{L}$ extracted DNA, ultra-pure distilled water $\left(\mathrm{Gibco}^{\circledR}\right)$ to a final volume of $25 \mu \mathrm{L}$. The primers amplify a gene fragment $u v r C$ with a 112 base pair product and show specificity for M. bovis using GenBank (Clothier et al. 2010) and are described in Table 1 . To determine the sensitivity of the PCR reaction, serial dilutions of pure culture M. bovis Donetta were prepared. All reactions were performed in duplicate in 96-well plates, sealed with optical seal film.

Modified Hayflick and SP4 insulation. For isolation of Mycoplasma species, $10 \mu \mathrm{L}$ of each PCR-positive milk sample was cultured for Mollicutes in supplemented Hayflick solid medium as described by Whitford et al. (1994) plus $0.01 \%$ thallium acetate (González \& Wilson 2003), as well as SP4 medium, according to Tully (1995). Incubation was performed in a 5\% microaerophilia environment in a $\mathrm{CO}_{2}$ greenhouse, observing microbial isolation three, five, seven, and 10 days after incubation. Microbial growth was monitored by the stereoscopic magnifying glass (Model ZEISS SteREO Discovery.V8), at $3 \mathrm{x}$ magnification; positive results are those with colonies with 
Table 1. Oligonucleotide sequences used in conventional and real-time PCR reactions for the detection of Mycoplasma bovis in bovine clinical mastitis in milk samples

\begin{tabular}{|c|c|c|c|c|}
\hline & Oligonucleotide sequence & Amplicon & Gene & Reference \\
\hline MGSO & 5' TGC ACC ATC TGT CAC TCT GTT AAC CT 3' & $270 \mathrm{pb}$ & 16S rRNA & Van Kuppeveld et al. (1992) \\
\hline GPO-3 & 5' GGG AGC AAA CAG GAT TAG ATA CCC T 3' & & & \\
\hline MBOf & 5' CCT TTT AGA TTG GGA TAG CGG ATG 3' & $360 \mathrm{pb}$ & 16S rRNA & González et al. (1995) \\
\hline Mbov F2024 & 5' TCT AAT TTT TTC ATC ATC GCT AAT GC 3' & $112 \mathrm{pb}$ & uvrC & Clothier et al. (2010) \\
\hline Mbov R2135 & 5’ TCA GGC CTT TGC TAC AAT GAA C 3’ & & & \\
\hline
\end{tabular}

characteristic "egg-fried" aspect (Pretto et al. 2001). Once positive, a colony was removed along with the culture medium and inoculated into broth Pleuropneumonia-like-organisms (PPLO) plus 1\% arginine for growth promotion. The isolates were identified by PCR to detect $M$. bovis.

16S rRNA gene sequencing of isolates. The sense and antisense sequences obtained as electropherograms were visualized in Chromas software version 2.6.5 (Technelysium Pty Ltd 1998-2018 ${ }^{\odot}$ ), and manually checked for edge removal and identification of errors or discrepancies. Next, the sequences were submitted to BLASTn ${ }^{1}$ in order to confirm the identity of the products obtained in PCR. They were then submitted to multiple alignments by the method ClustalW in the MEGA X program (Kumar et al. 2018), along with 13 other sequences from eight different mycoplasma species, including species whose isolation from bovine dairy cattle were reported in the literature (Gioia et al. 2016). The sequence of the M. bovis Donetta strain, used as a positive control in PCR assays, was also included.

The phylogenetic reconstruction was also performed in the MEGA X program by the Maximum Likelihood method, using the replacement model Kimura 2-parameter, assuming that some sites were evolutionarily invariable ([+ I], 66.24\%) (Kimura 1980). This replacement model was defined as the most appropriate to the database, determined by the model selection procedure in MEGAX, and the one with the lowest score under the Bayesian Information Criterion (BIC). The consensus tree was inferred from 1000 Bootstrap replicates (Felsenstein 1985). The first trees for the heuristic search were obtained automatically by applying Neighbor-Join and BioNJ algorithms in an array of estimated peer distances using the Maximum Composite Likelihood (MCL), then selecting the topology with superior log likelihood value.

\section{Molecular analysis}

\section{RESULTS}

Regarding the 1,166 milk samples analyzed from clinical mastitis cases, $8.6 \%(100 / 1166)$ were positive in molecular detection for class Mollicutes. By investigating the presence of $M$. bovis in the 100 positive samples for class Mollicutes, $1.1 \%(13 / 1166)$ positive results for conventional PCR were obtained, while real-time PCR was $0.9 \%(11 / 1166)$. The positive results at least presented in one of the molecular analyzes for detection of M. bovis was $1.4 \%$ (16/1166) in five of the ten properties evaluated.

Considering the positive result for M. bovis, in any of the techniques used in this study, either molecular or microbiological

\footnotetext{
${ }^{1}$ Nucleotide Basic Local Alignment Search Tool (BLAST), National Center for Biotechnology Information (NCBI), U.S. National Library of Medicine, Bethesda, Maryland, USA. Available at <http://www.ncbi.nlm.nih.gov/ BLAST>
}

analysis, $1.5 \%(17 / 1166)$ of positive samples for this agent was obtained.

Three samples were negative to conventional PCR for M. bovis, however, positive samples were detected in real-time PCR. Eight samples were positive in both molecular tests. Five samples were negative for real-time PCR and positive for conventional PCR.

Considering that convenience samples were chosen among a total of 10 properties, with at least one positive milk sample for $M$. bovis, 50\% (5/10 - A, B, C, D, and F) of the properties were positive for $M$. bovis when evaluated by molecular techniques.

\section{Sequencing analysis}

Concerning to the amplified product of the isolates and sequencing, the isolates were similarly grouped for M. bovis, confirming the results obtained in PCR from the analysis of clinical mastitis milk. Two negative isolates for conventional PCR in M. bovis were also grouped with similarity to the same agent in the phylogenetic analysis.

\section{Microbiological analysis}

The 100 PCR-positive milk samples for class Mollicutes were grown in modified Hayflick medium, and SP4 supplemented medium. Isolation of 6\% (6/100) for the genus Mycoplasma were obtained from Hayflick, and 11\% (11/100) from SP4, and all Hayflick positive samples were also SP4 positive. SP4 culture medium has been shown to be 18.8 times higher for isolation of the genus Mycoplasma $(\mathrm{P}=0.0253)$ when compared to isolation of Mycoplasma in Hayflick medium (95\% IC=8.01-44.05).

One sample was negative in both molecular tests for $M$. bovis detection originated from the clinical mastitis in milk samples. However, there was a growth of colonies in the microbiological culture. The isolate obtained after cultivation was confirmed as M. bovis in conventional PCR technique.

Three analyzed clinical mastitis in milk samples were positive for all tests performed: conventional and real-time PCR, Hayflick medium, and SP4 medium.

\section{DISCUSSION}

\section{Molecular analysis}

The $M$. bovis research on bovine milk samples is widely performed due to the higher prevalence and importance of this pathogen in the etiology of mastitis, reported in previous studies (Aebi et al. 2012, Higuchi et al. 2013, Gioia et al. 2016). The detection of $1.4 \%$ of this species obtained in the 
present study is lower than that reported by other authors (Higuchi et al. 2013, Lysnyansky et al. 2016).

It is important to note that no studies are referred to the etiology of Mycoplasma spp. infection in the mammary glands in Brazil, this way being difficult to compare the occurrence of the most prevalent species of this agent in the country. The literature provides data related only to the occurrence of M. bovis in dairy herds. In milk expansion tanks, Manzi et al. (2018) obtained a 1.4\% prevalence of $M$. bovis, in 67 tank samples analyzed. Junqueira et al. (2017) analyzed milk samples from clinical mastitis and reported the occurrence of $3 \%$ of $M$. bovis detected by conventional PCR.

On the other hand, in other countries, the occurrence of other Mycoplasma spp. is widely studied. In a study conducted in Japan, Higuchi et al. (2013) obtained 89\% (184/208) of fourth breasts infected with only one species of mycoplasma, being: $M$. bovis the most prevalent, followed by M. alkalescense, $M$. californicum, M. arginini, $M$. canadense, $M$. bovigenitalium and $M$. adleri. Furthermore, it is noted that some animals were coinfected with more than one species of Mycoplasma.

In New York State, United States of America (USA), the prevalence of $M$. bovis was reported to be highest among other Mycoplasma spp.. Gioia et al. (2016) described the occurrence of the following species of class Mollicutes, responsable for causing mastitis: $78 \%$ of $M$. bovis; $17 \%$ of M. alkalescens; $11 \%$ of Acholeplasma laidlawii; $10 \%$ of $M$. bovigenitalium; $10 \%$ of $M$. canadense; $3 \%$ of $M$. californicum; $2 \%$ of $M$. arginini; $2 \%$ of Acholeplasma oculi and 1\% M. bovirhinis.

PCR is a molecular tool widely used in research involving a variety of samples, including milk samples. One of the obstacles to this technique is the presence of Taq polymerase inhibitors that may trigger false negative reactions. These inhibitors may be from the sample itself or introduced during some reaction step. Milk samples naturally have calcium and fat in their composition, which may inhibit PCR depending on the concentrations (Schrader et al. 2012). Powell et al. (1994) could find in milk, a natural Taq polymerase inhibitor, in other words, plasmin, a component capable of inhibiting the PCR reaction.

It is suggested the presence of some PCR inhibitor in the milk of one of the evaluated samples. The referred clinical sample was decisive in the detection of class Mollicutes; on the other hand, had a negative impact on both molecular techniques for the detection of $M$. bovis. However, it was positive in microbiological culture for that species. This fact suggests a false negative result for $M$. bovis from milk analysis. The possibility of a low concentration of DNA from $M$. bovis in the clinical sample may be related to this finding. Real-time PCR amplifies specific regions of the bacterial genome from minimal amounts of DNA (Valasek \& Repa 2005), and real-time PCR is more sensitive than conventional PCR. However, this sensitivity depends directly on the quality of genomic DNA. Templeton et al. (2003) compared diagnostic techniques for the detection of $M$. pneumoniae and concluded that real-time PCR is more sensitive, specific, and superior to conventional PCR in detecting the pathogen in samples from adult patients with infection of lower respiratory tract. The present study did not evaluate the sensitivity between the two techniques in the detection of $M$. bovis.

The thermolysis method is a "non-onerous" and simple option, but it could be detected results with lower DNA quality
DNA than commercial kits, with proteins or other PCR inhibitors. However, it is a feasible technique for diagnosing Mycoplasma spp. in milk, with excellent results obtained and already standardized. The group decided to perform the extraction by this method, followed by a protocol of DNA purification to obtain a better quality analytical material, taking into account the costs and practicality of the method. For conventional PCR, it was possible to use thermolysis method with satisfactory results in detecting $M$. canadense and $M$. californicum from isolates of milk samples (Tamiozzo et al. 2014).

In the present study, the efficiency of extracted DNA was not evaluated for the presence of inhibitors or cell lysis, and also the thermolysis protocols were not compared with other data, so it could not be affirmed if false-negative results were resulting from poor DNA quality, by considering the DNA extraction used.

The differentiation of $M$. agalactiae and $M$. bovis species from the sequence of their 16s rRNA is difficult to detect due to their high similarity between their 16s rRNA (Königsson et al. 2002, Bashiruddin et al. 2005). Among the isolates obtained in the present study, two of them were opposite to conventional PCR for positive $M$. bovis from bovine clinical mastitis in milk sample for the same agent. In sequencing analysis, the results from the isolates were grouped in cluster that includes the species M. bovis and M. agalactiae, due to the high similarity between them.

Given the positive molecular results for M. bovis obtained from clinical mastitis in milk samples, it is suggested that two species, even without the amplification of the isolate, would be responsible for their epidemiology in animals. However, it is suggested to use other primers and further studies to investigate variations or mutations that may be occurring in these isolates to confirm this theory (Lysnyansky et al. 2008).

The epidemiology of the two species, M. bovis and $M$. agalactiae in animals, are distinct. The first occurs in cattle, mainly causing mastitis, pneumonia, and arthritis (Pfützner \& Sachse 1996), and the second, in small ruminants, responsible for contagious agalactia (González et al. 1995). There are reports of the incidence of $M$. agalactiae in bulls with the involvement of ocular, cerebral, and auditory canal (Catania et al. 2016), however, regarding mastitis, there are no reports so far.

The properties evaluated in the present study use high technology for the production of bovine milk and no goat or sheep rearing; therefore, $M$. agalactiae bovine mastitis is unlikely to occur in this study.

\section{Microbiological analysis}

The difficulty in isolating Mycoplasma spp. in culture medium is known due to the characteristics related to the different species. To growth the detection of other species, two culture media were used in the present study, but there was no growth of different species of $M$. bovis.

Modified Hayflick medium is recommended for the isolation of $M$. bovis in milk samples (Pfützner \& Sachse 1996) and successfully used by several authors (Pretto et al. 2001, Cai et al. 2005, Riekerink et al. 2006). The use of more than one culture medium may increase the isolation rate of Mycoplasma spp., as observed by Lai et al. (1986), when comparing Chalquest and Hayflick's means for detecting M. pulmonis, with $92 \%$ and $66 \%$ bacterial isolation, respectively. 
Tortorelli et al. (2017) obtained only positive isolation on Hayflick medium in 32 sections of bovine respiratory disease, stressing a low percentage when compared to other studies. The authors also observed that the result of bacterial isolation is often not associated with PCR in a positive way, comprising negative molecular and positive culture results. This result could also be observed in the present study.

The samples used in this study were satisfactory, i.e., referred for diagnosis of Mycoplasma spp. in different herds. All samples were obtained frozen and kept at freezing temperature for a period of up to one month to be processed. Freezing causes a decrease in the number of viable microorganisms that cannot be recovered in microbiological cultivation (Parker et al. 2018). The low isolation rate obtained in the present study may be associated with freezing or thawing of milk samples, viable microbial load reduction, and the possibility of false-negative results in microbiological culture.

The occurrence of negative results to the microbiological culture associated with concomitant positive PCR results is reported in the literature (Férandon et al. 2011). Positive results in microbiological cultivation may vary between different studies. The use of more than one type of culture medium can influence the results positively since it is known that mycoplasma species present different mechanisms of bacterial growth. Férandon et al. (2011) obtained 29.4\% $(45 / 153)$ of positive results in the microbiological culture, superior to that obtained in the present study, which was $11 \%$, and may be related to the quality and cell viability of the samples analyzed.

The high percentage of negative samples in the culture can be mainly due to the possibility of cellular unfeasibility. However, the culture medium was not specific for all Mycoplasma spp., considering that only $M$. bovis was identified in PCR. In addition to these aspects, the possibility of other pathogens present in the samples should be considered, seeing that may occur microbial competition, thus hinder the isolation of Mycoplasma spp., considering the longer time required for isolation.

It is expected that the PCR results may outperform microbiological culture, whereas detecting degenerate DNA from non-viable mycoplasmas or negative cultures may contain a low concentration of detectable DNA in PCR. This finding was observed in the present study, with $89 \%$ of negative samples in microbiological culture.

\section{CONCLUSION}

It was possible to confirm the presence of $M$. bovis by using genetic sequencing. The use of SP 4 culture medium increased the detection rate of viable mycoplasmas when compared to Hayflick's medium, and its use is satisfactory for the microbiological diagnosis of $M$. mastitis.

Acknowledgments.- To the Coordenação de Aperfeiçoamento de Pessoal de Nivel Superior (CAPES), for the doctoral scholarship. To the team led by Professor Jorge Timenetsky for their support in real-time PCR development and the granting of positive control for the analyzes.

Conflict of interest statement.- The authors have no competing interests.

\section{REFERENCES}

Aebi M., Bodmer M., Frey J. \& Pilo P. 2012. Herd-specific strains of Mycoplasma bovis in outbreaks of mycoplasmal mastitis and pneumonia. Vet. Microbiol. 157(3):363-368. <http://dx.doi.org/10.1016/j.vetmic.2012.01.006> $<$ PMid:22306036>
Al-Farha A.A.-B., Hemmatzadeh F., Khazandi M., Hoare A. \& Petrovski K. 2017. Evaluation of effects of Mycoplasma mastitis on milk composition in dairy cattle from South Australia. BMC Vet. Res. 13(1):351. <http://dx.doi. org/10.1186/s12917-017-1274-2><PMid:29178880>

Arcangioli M.A., Chazel M., Sellal E., Botrel M.A., Bezille P., Poumarat F., Calavas D. \& Le Grand D. 2011. Prevalence of Mycoplasma bovis udder infection in dairy cattle: preliminary field investigation in southeast France. N. Z. Vet. J. 59(2):75-78. <http://dx.doi.org/10.1080/00480169.2011.55285 6><PMid:21409733>

Baird S.C., Carman J., Dinsmore R.P., Walker R.L. \& Collins J.K. 1999. Detection and identification of Mycoplasma from bovine mastitis infections using a nested polymerase chain reaction. J. Vet. Diagn. Invest. 11(5):432-435. <http://dx.doi.org/10.1177/104063879901100507><PMid:12968756>

Bashiruddin J.B., Frey J., Königsson M.H., Johansson K.-E., Hotzel H., Diller R., de Santis P., Botelho A., Ayling R.D., Nicholas R.A.J., Thiaucourt F. \& Sachse K. 2005. Evaluation of PCR systems for the identification and differentiation of Mycoplasma agalactiae and Mycoplasma bovis: a collaborative trial. Vet. J. 169(2):268-275. <http://dx.doi.org/10.1016/j.tvjl.2004.01.018> <PMid:15727920>

Brown D.R., May M., Bradbury J.M., Balish M.F., Calcutt M.J., Glass J.I., Tasker S., Messick J.B., Johansson K.E. \& Neimark H. 2010. Genus I, Mycoplasma, p.575-613. In: Krieg N.R., Staley J.T., Hedlund B., Paster B.J., Ward N., Ludwig W., \& Whitman W.B. (Eds), Bergey's Manual of Systematic Bacteriology. 2nd ed. Springer, New York.

Cai H.Y., Bell-Rogers P., Parker L. \& Prescott J.F. 2005. Development of a real-time PCR for detection of Mycoplasma bovis in bovine milk and lung samples. J. Vet. Diagn. Invest. 17(6):537-545. <http://dx.doi. org/10.1177/104063870501700603><PMid:16475511>

Catania S., Gobbo F., Schiavon E. \& Nicholas R.A. 2016. Severe otitis and pneumonia in adult cattle with mixed infection of Mycoplasma bovis and Mycoplasma agalactiae. Vet. Rec. Case Rep. 4(2):e000366. <http://dx.doi. org/10.1136/vetreccr-2016-000366>

Clothier K.A., Jordan D.M., Thompson C.J., Kinyon J.M., Frana T.S. \& Strait E.L. 2010. Mycoplasma bovis real-time polymerase chain reaction assay validation and diagnostic performance. J. Vet. Diagn. Invest. 22(6):956-960. <http://dx.doi.org/10.1177/104063871002200618><PMid:21088183>

Fan H.H., Kleven S.H. \& Jackwood M.W. 1995. Application of polymerase chain reaction with arbitrary to strain identification of Mycoplasma gallisepticum. Avian Dis. 39(4):729-735. <http://dx.doi.org/10.2307/1592409> $<$ PMid:8719206>

Felsenstein J. 1985. Confidence limits on phylogenies: An approach using the bootstrap. Evolution 39(4):783-791. <http://dx.doi. org/10.1111/j.1558-5646.1985.tb00420.x ><PMid:28561359>

Férandon C., Peuchant O., Janis C., Benard A., Renaudin H., Pereyre S. \& Bébéar C. 2011. Development of a real-time PCR targeting the yidC gene for the detection of Mycoplasma hominis and comparison with quantitative culture. Clin. Microbiol. Infect. 17(2):155-159. <http://dx.doi. org/10.1111/j.1469-0691.2010.03217.x><PMid:20298269>

Gioia G., Werner B., Nydam D.V. \& Moroni P. 2016. Validation of a mycoplasma molecular diagnostic test and distribution of mycoplasma species in bovine milk among New York State dairy farms. J. Dairy Sci. 99(6):4668-4677. <http://dx.doi.org/10.3168/jds.2015-10724><PMid:27016831>

González R.N. \& Wilson D.J. 2003. Mycoplasmal mastitis in dairy herds. Vet. Clin. N. Am. Food Anim. Pract. 19(1):199-221. <http://dx.doi.org/10.1016/ S0749-0720(02)00076-2><PMid:12682943>

González Y.R.C., Bascuñana C.R., Bölske G., Mattsson J.G., Molina C.F. \& Johansson K.E. 1995. In vitro amplification of the $16 \mathrm{~S}$ rRNA genes from Mycoplasma bovis and Mycoplasma agalactiae by PCR. Vet. Microbiol. 47(1/2):183-190. <http://dx.doi.org/10.1016/0378-1135(95)00058-I><PMid:8604550>

Higuchi H., Gondaira S., Iwano H., Hirose K., Nakajima K., Kawai K., Hagiwara K., Tamura Y. \& Nagahata H. 2013. Mycoplasma species isolated from 
intramammary infection of Japanese dairy cows. Vet. Rec. 172(21):557. <http://dx.doi.org/10.1136/vr.101228><PMid:23457142>

Junqueira N.B., Oliveira G.C., Salina A., Guimaraes F.F., Joaquim S.F., Latosinski G.S. \& Langoni H. 2017. Mastitis caused by Mycoplasma bovis in Brazil. Proceedings of the XVIII International Congress of the International Society for Animal Hygiene "International Co-operation and Solidarity in Animal Hygiene towards One Health", Mazatlan, Mexico, p.195-197.

Kazemiha V.M., Shokrgozar M.A., Arabestani M.R., Moghadam M.S., Azari S., Maleki S., Amanzadeh A., Tehrani M.J. \& Shokri F. 2009. PCR-based detection and eradication of mycoplasmal infections from various mammalian cell lines: a local experience. Cytotechnology 61(3):117-124. <http://dx.doi. org/10.1007/s10616-010-9252-6><PMid:20135349>

Kimura M. 1980. A simple method for estimating evolutionary rates of base substitutions through comparative studies of nucleotide sequences. J. Mol. Evol. 16(2):111-120. <http://dx.doi.org/10.1007/BF01731581> $<$ PMid:7463489>

Königsson M.H., Bölske G. \& Johansson K.E. 2002. Intraspecific variation in the 16S rRNA gene sequences of Mycoplasma agalactiae and Mycoplasma bovis strains. Vet. Microbiol. 85(3):209-220.<http://dx.doi.org/10.1016/ S0378-1135(01)00517-X> <PMid:11852188>

Kumar S., Stecher G., Li M., Knyaz C. \& Tamura K. 2018. MEGA X: molecular evolutionary genetics analysis across computing platforms. Mol. Biol. Evol. 35(6):1547-1549. <http://dx.doi.org/10.1093/molbev/msy096> <PMid:29722887>

Lai W.C., Pakes S.P., Stefanu C. \& Lu Y.S. 1986. Comparison of Chalquest and Hayflick media, with and without ammonium reineckate, for isolating Mycoplasma pulmonis from rats. J. Clin. Microbiol. 23(5):817-821.<http:// dx.doi.org/10.1128/JCM.23.5.817-821.1986><PMid:3711268>

Lysnyansky I., Freed M., Rosales R.S., Mikula I., Khateb N., Gerchman I., van Straten M. \& Levisohn S. 2016. An overview of Mycoplasma bovis mastitis in Israel (2004-2014). Vet. J. 207:180-183. <http://dx.doi.org/10.1016/j. tvjl.2015.10.057><PMid:26626090>

Lysnyansky I., Yogev D. \& Levisohn S. 2008. Molecular characterization of the Mycoplasma bovis $\mathrm{p} 68$ gene, encoding a basic membrane protein with homology to P48 of Mycoplasma agalactiae. FEMS Microbiol. Letters 279(2):234-242. <http://dx.doi.org/10.1111/j.1574-6968.2007.01040. $\mathrm{x}><$ PMid:18194339>

Manzi M.P., Joaquim S.F., Guimarães F.F., Bruder-Nascimento A.C.M.O., Pantoja J.C.F. \& Langoni H. 2018. Prevalência de Mycoplasma bovis em rebanhos de vacas leiteiras. Pesq. Vet. Bras. 38(4):665-669. <http://dx.doi. org/10.1590/1678-5150-pvb-5192>

Mettifogo E., Nascimento E.R., Müller E.E., Nascimento M.G.F. \& Freitas J.C. 1996. Mastite bovina por Mycoplasma bovis. Revta Bras. Med. Vet. 18:22-25.

Nicholas R.A.J., Fox L.K. \& Lysnyansky I. 2016. Mycoplasma mastitis in cattle: to cull or not to cull. Vet. J. 216:142-147. <http://dx.doi.org/10.1016/j. tvjl.2016.08.001><PMid:27687942>

Parker A.M., Sheehy P.A., Hazelton M.S., Bosward K.L. \& House J.K. 2018. A review of Mycoplasma diagnostics in cattle. J. Vet. Intern.
Med. 32(3):1241-1252. <http://dx.doi.org/10.1111/jvim.15135> <PMid:29671903>

Pfützner H. \& Sachse K. 1996. Mycoplasma bovis as an agent of mastitis, pneumonia, arthritis and genital disorders in cattle. Rev. Sci. Tech. Off. Int. Epiz. 15(4):1477-1494. <http://dx.doi.org/10.20506/rst.15.4.987> <PMid:9190022>

Powell H.A., Gooding C.M., Garrett S.D., Lund B.M. \& McKee R.A. 1994. Proteinase inhibition of the detection of Listeria monocytogenes in milk using the polymerase chain reaction. Letters Appl. Microbiol. 18(1):59-61. <http://dx.doi.org/10.1111/j.1472-765X.1994.tb00802.x>

Pretto L.G., Müller E.E., Freitas J.C., Mettifogo E., Buzinhani M., Yamaguti M. \& Salvador R. 2001. Mastite bovina por Mycoplasma bovis em rebanhos leiteiros. Pesq. Vet. Bras. 21(4):143-145. <http://dx.doi.org/10.1590/ S0100-736X2001000400003>

Riekerink R.G.O., Barkema H.W., Veenstra S., Poole D.E., Dingwell R.T. \& Keefe G.P. 2006. Prevalence of contagious mastitis pathogens in bulk tank milk in Prince Edward Island. Can. Vet. J. 47(6):567-572. <PMid:16808229>

Schrader C., Schielke A., Ellerbroek L. \& Johne R. 2012. PCR inhibitors occurrence, properties and removal. J. Appl. Microbiol. 113(5):1014-1026. <http://dx.doi.org/10.1111/j.1365-2672.2012.05384.x><PMid:22747964>

Tamiozzo P.J., Estanguet A.A., Maito J., Tirante L., Pol M. \& Giraudo J.A. 2014. Detección de Mycoplasma canadense y Mycoplasma californicum en ganado lechero de Argentina. Revta Argentina Microbiol. 46(2):119-121.<http:// dx.doi.org/10.1016/S0325-7541(14)70059-8> <PMid:25011595>

Templeton K.E., Scheltinga S.A., Graffelman A.W., Van Schie J.M., Crielaard J.W., Sillekens P., Van Den Broek P.J., Goossens H., Beersma M.F.C. \& Claas E.C.J. 2003. Comparison and evaluation of real-time PCR, real-time nucleic acid sequence-based amplification, conventional PCR, and serology for diagnosis of Mycoplasma pneumoniae. J. Clin. Microbiol. 41(9):4366-4371. <http://dx.doi.org/10.1128/JCM.41.9.4366-4371.2003><PMid:12958270>

Tortorelli G., Gaeta N.C., Ribeiro B.L.M., Marques L.M., Timenetsky J. \& Gregory L. 2017. Evaluation of Mollicutes microorganisms in respiratory disease of cattle and their relationship to clinical signs. J. Vet. Intern. Med. 31(4):12151220. <http://dx.doi.org/10.1111/jvim.14721><PMid:28602021>

Tully J.G. 1995. Culture medium formulation for primary isolation and maintenance of Mollicutes, p.33-39. In: Razin S. \& Tully J.G (Eds), Molecular and Diagnostic Procedures in Mycoplasmology. Academic Press, San Diego. <http://dx.doi.org/10.1016/B978-012583805-4/50005-4>.

Valasek M.A. \& Repa J.J. 2005. The power of real-time PCR. Adv. Physiol. Educ. 29(3):151-159. <http://dx.doi.org/10.1152/advan.00019.2005> <PMid:16109794>

Van Kuppeveld F.J.M., Van Der Logt J.T.M., Angulo A.F., Van Zoest M.J., Quint W.G., Niesters H.G., Galama J.M. \& Melchers W.J. 1992. Genus: and speciesspecific identification of mycoplasmas by 16S rRNA amplification. Appl. Environ. Microbiol. 58(8):2606-2615. <http://dx.doi.org/10.1128/ AEM.58.8.2606-2615.1992><PMid:1381174>

Whitford H.W., Rosenbusch R.F. \& Lauerman L.H. 1994. Mycoplasmosis in Animals: laboratory diagnosis. Iowa State University, Ames. 150p. 